\title{
Investigating the adoption of big data analytics in healthcare: the moderating role of resistance to change
}

\author{
Muhammad Shahbaz* ${ }^{*}$, Changyuan Gao*, LiLi Zhai, Fakhar Shahzad and Yanling Hu
}

\author{
*Correspondence: \\ shahbaz755@yahoo.com; \\ gaocy2002@126.com \\ School of Economics \\ and Management, Harbin \\ University of Science \\ and Technology, Harbin, \\ China
}

\begin{abstract}
Big data analytics is gaining substantial attention due to its innovative contribution to decision making and strategic development across the healthcare field. Therefore, this study explored the adoption mechanism of big data analytics in healthcare organizations to inspect elements correlated to behavioral intention using the technology acceptance model and task-technology fit paradigm. Using a survey questionnaire, we analyzed 224 valid responses in AMOS v21 to test the hypotheses. Our results posit that the credentials of the technology acceptance model together with task-technology fit contribute substantially to the enhancement of behavioral intentions to use the big data analytics system in healthcare, ultimately leading towards actual use. Meanwhile, trust in and security of the information system also positively influenced the behavioral intention for use. Employee resistance to change is a key factor underlying failure of the innovative system in organizations and has been proven in this study to negatively moderate the relationship between intention to use and actual use of big data analytics in healthcare. Our results can be implemented by healthcare organizations to develop an understanding of the implementation of big data analytics and to promote psychological empowerment of employees to accept this innovative system.
\end{abstract}

Keywords: Big data analytics, Healthcare, Trust

\section{Introduction}

Big data analytics (BDA) is a course of action to examine large and complex data sets (i.e., big data) and select veiled information that can help organizations with efficient decision making [1]. The volume of data related to healthcare organizations has grown dramatically in past years and is expected to increase in coming years due to the use of innovative technologies [2]. Meanwhile, healthcare reimbursement methods are changing, and pay for performance is an emerging factor in the current healthcare environment. Recently, healthcare organizations have only focused on profit and have neglected to acquire the essential tools, infrastructure, and technologies for effective control of big data to ensure citizens' health care [3, 4]. Big data incorporates features such as variety, velocity, and veracity. BDA techniques can be applied to the massive amount of prevailing patient-related medical information to analyze outcomes for improvement of the healthcare sector $[5,6]$. Using BDA in the healthcare sector will help inform each physician of the medical histories of individuals and the population and enable appropriate

(c) The Author(s) 2019. This article is distributed under the terms of the Creative Commons Attribution 4.0 International License (http://creativecommons.org/licenses/by/4.0/), which permits unrestricted use, distribution, and reproduction in any medium, provided you give appropriate credit to the original author(s) and the source, provide a link to the Creative Commons license, and indicate if changes were made. 
decision-making regarding treatment of a particular patient [4]. However, compared with the banking and retailing industries, healthcare organizations have lagged behind in the sophisticated use of BDA [7]. The healthcare industry also strives to make internal developments in BDA implementation based on their quality and data performance, which provides timely feedback to interested parties [8]. Therefore, describing the crucial factors that are required for understanding is important prior to creating a strategy for the acceptance of BDA in the healthcare industry, particularly in developing countries such as Pakistan, where the industry requires filling the gap of BDA adoption. Furthermore, data (i.e., big data) related to healthcare are generated at a very high pace [9], and existing systems are unable to store and analyze the huge volume, velocity and variety of data [10]. Therefore, a need exists for a system with the ability to store and analyze data with high volumes, velocities, and variety, all of which are provided by BDA systems [9]. BDA is in the initial adoption phase, and many healthcare organizations want to implement BDA to obtain its benefits [11]. Thus, a comprehensive adoption model related to $\mathrm{BDA}$ is needed to fulfill the existing gap in the literature and help healthcare organizations replace traditional systems incapable of competing with BDA systems.

Few studies have described the importance of BDA in healthcare [4, 12, 13], although studies have investigated the technological aspects and required qualifications for big data in healthcare [14-18]. Previous studies focused on technological and policy issues and not on adoption factors, such as security, trust, and fitness of technology for the tasks required to manage BDA in healthcare [13]. According to Dishaw [19], the technology acceptance model (TAM) and task-technology fit (TTF) provide better outputs than either TAM or TTF alone in the adoption of information technology systems. The prior literature tries to explain BDA adoption through perceptions of technology, such as perceived ease of use and perceived usefulness [20-24]. However, emphasizing only the end user's perception of technology may not be sufficient. According to Goodhue and Thompson [25], the TTF model claims that the user will adopt the system when the characteristics of the technology fit the task requirements. Adoption will also occur when the user perceives the technology as useful, easy and advanced, but the technology may not be adopted if a mismatch exists with his required tasks and the technology cannot enhance his job performance [26-29]. Therefore, not only should the user have the perception that the technology is useful and easy but also the technology characteristics should match with the required job tasks. Furthermore, the previous literature showed that perceived security of information [30-32] and perceived trust [33-35] were the biggest hurdles for users adopting innovative information systems. Security of information is the main reason for the slow pace of BDA adoption [36, 37]. Perceived trust is a major concern in the BDA acceptance procedure, and thus organizations should generate more trust in BDA adoption [38]. Prior studies by Malaka, Shin, and Sivarajah $[23,39,40]$ also highlighted that perceived security and perceived trust were the biggest challenges and hurdles for BDA acceptance. Resistance to change (RTC) from employees is also a key factor that affects the adoption of different innovative systems, especially in developing countries [41-43]. In previous literature concerning electronic health record system adoption, RTC from physicians was repeatedly reported as a key barrier for system adoption [44, 45], and RTC of employees mitigated the willingness of those who wanted to adopt the system [46]. RTC also resists or slow down the pace of information 
system acceptance in the health sector $[47,48]$. The study considers RTC a key factor in the adoption of BDA in the healthcare sector, which has never been discussed in this scenario.

Despite the fame of BDA, insufficient empirical research has investigated factors that can influence BDA adoption in healthcare [21, 49]. Empirical evidence from Pakistan's healthcare organizations represents a big gap in the literature from both dimensions (i.e., knowledge about BDA and adoption of BDA) [50]. This study summarizes real facts from Pakistan for the healthcare BDA literature. The gap between the potential pros of BDA and the slow and low geared adoption represents a superior opportunity for scholars to realize how BDA can be adopted in the healthcare industry. BDA is in the initial adoption phase in Pakistan, and the government should develop a clear policy and mechanism for the acceptance of BDA in government and the private sector [50]. Therefore, to bridge this gap in the literature, the major focus of this paper is to provide comprehensive research insights into the adoption of BDA in healthcare. To fulfill said gap, the study has two main objectives. The first objective is to help government and private healthcare organizations determine the important factors that play key roles in the adoption of BDA in healthcare in developing countries, such as Pakistan. The second objective is to cover the on-hand gap in the literature concerning the influence of RTC from employees for BDA adoption. To achieve the above-mentioned objectives, this study incorporated both TAM and TTF models to explain BDA adoption in the healthcare sector from both viewpoints (the user's perception of technology and the task-technology fitness) with the most important and substantial factors involved in the adoption of information systems (i.e., perceived security and perceived trust). The study also considers RTC as a moderator in the proposed model to address the most important hurdle for developing countries, such as Pakistan [33, 41]. The results justified the use of a composite of both TAM and TTF with security and trust as significant predictors of behavioral intentions (BIs) to adopt BDA, whereas RTC negatively moderated the relationship between BIs and actual use of BDA.

In the next section, we describe the theoretical background and develop a research model for this study to analyze the predictors linked to BDA adoption. The research methods are discussed in section three, and section four provides results from our data analysis using structural equation modeling and discussions. "Conclusion" section concludes the overall findings. In addition to the research limitations, our study also has theoretical and practical implications, as discussed in "Conclusion" section. References are given in "Reference" section.

\section{Relevant work and hypotheses}

During this phase, we underpin the relevant theories and work based on the prior literature regarding the acceptance of a BDA system across various sectors (see Table 1) and produce the research hypotheses for analysis based on the research framework (see Fig. 1).

\section{Perceived trust}

Trust is described as a belief that a person or a particular thing will respond in a helpful way without manipulating the results [60]. Perceived trust is a state of mind in which 
Table 1 Relevant work

\begin{tabular}{|c|c|c|c|}
\hline Authors & Year & Important aspects & Limitations \\
\hline Esteves and Curto [21] & 2013 & $\begin{array}{l}\text { Predicted behavioral intention to use } \\
\text { big data technology by using the } \\
\text { theory of planed behavior based on } \\
\text { risk and benefits point of view }\end{array}$ & $\begin{array}{l}\text { Small sample size was used to test the } \\
\text { proposed model and insufficient } \\
\text { theoretical base provided }\end{array}$ \\
\hline Mahmood and Afzal [51] & 2013 & $\begin{array}{l}\text { Provided survey on description, tech- } \\
\text { nology, trend, and tools of cyber- } \\
\text { crime security in Pakistan by using } \\
\text { big data analytics }\end{array}$ & $\begin{array}{l}\text { Big data analytics adoption model not } \\
\text { provided }\end{array}$ \\
\hline Tsai et al. [52] & 2015 & $\begin{array}{l}\text { Provided a brief introduction of big } \\
\text { data analytics to help in developing } \\
\text { high performance platform and min- } \\
\text { ing algorithm for big data analytics }\end{array}$ & $\begin{array}{l}\text { Did Not predict the behavior of a user } \\
\text { regarding use of big data analytics }\end{array}$ \\
\hline Malaka and Brown [40] & 2015 & $\begin{array}{l}\text { Investigated the adoption of big data } \\
\text { analytics in organization prospective } \\
\text { by using technology organization } \\
\text { environment model }\end{array}$ & $\begin{array}{l}\text { User centric approach was ignored by } \\
\text { the study }\end{array}$ \\
\hline Archenaa and Anita [53] & 2015 & $\begin{array}{l}\text { Conducted a survey to explore the } \\
\text { importance, benefits, and need of } \\
\text { big data analytics in healthcare and } \\
\text { government }\end{array}$ & $\begin{array}{l}\text { Empirical evidence regarding adoption } \\
\text { from citizen prospective and security } \\
\text { of information was ignored in the } \\
\text { study }\end{array}$ \\
\hline Soon et al. [54] & 2016 & $\begin{array}{l}\text { Demonstrated the big data analytics } \\
\text { adoption by using the technology } \\
\text { acceptance model and diffusion of } \\
\text { innovation model and explored the } \\
\text { moderating effects of training in } \\
\text { Malaysia }\end{array}$ & $\begin{array}{l}\text { The scope of the study was restricted } \\
\text { to only private organizations which } \\
\text { inferred the generalization of the } \\
\text { study }\end{array}$ \\
\hline LaBrie et al. [55] & 2017 & $\begin{array}{l}\text { Provided a comparative study of china } \\
\text { and USA to understand the technol- } \\
\text { ogy change and big data analytics } \\
\text { adoption from a societal perspective }\end{array}$ & $\begin{array}{l}\text { Study missed the fit between technol- } \\
\text { ogy and cultural dimensions of } \\
\text { people }\end{array}$ \\
\hline Sivarajah et al. [39] & 2017 & $\begin{array}{l}\text { The systematic literature view was } \\
\text { performed to identify the challenges } \\
\text { in big data analytics }\end{array}$ & $\begin{array}{l}\text { To develop the link between theories } \\
\text { and practice the empirical analysis } \\
\text { was not performed }\end{array}$ \\
\hline Memon et al. [56] & 2017 & $\begin{array}{l}\text { Apache Hadoop open source technol- } \\
\text { ogy was used to check the big data } \\
\text { analytics application in the healthcare } \\
\text { sector of Pakistan }\end{array}$ & $\begin{array}{l}\text { Big data analytics application from a } \\
\text { user's perspective in the healthcare } \\
\text { sector of Pakistan was not provided }\end{array}$ \\
\hline Brock and Khan [24] & 2017 & $\begin{array}{l}\text { Combined technology acceptance } \\
\text { model and organization learning } \\
\text { capabilities to explore the factors } \\
\text { linked with big data analytics usage }\end{array}$ & $\begin{array}{l}\text { Pre-implementation assessment for } \\
\text { practitioners was not performed } \\
\text { considering the user's perspective in } \\
\text { the adoption of big data analytics }\end{array}$ \\
\hline Weerakkody et al. [57] & 2017 & $\begin{array}{l}\text { To investigate the user's behavioral } \\
\text { intentions of big open data. The } \\
\text { study applied extended technology } \\
\text { acceptance model }\end{array}$ & $\begin{array}{l}\text { The study only focused on intention to } \\
\text { use only instead of focusing also on } \\
\text { actual use of big open data }\end{array}$ \\
\hline Arunachalam et al. [58] & 2018 & \multicolumn{2}{|c|}{$\begin{array}{l}\text { Provided comprehensive literature viewA phenomenon of restriction to } \\
\text { on capabilities of big data analytics change in the user perspective was } \\
\text { to demonstrate the challenges which not discussed } \\
\text { help to develop a big data analytics } \\
\text { maturity model }\end{array}$} \\
\hline Gupta et al. [59] & 2018 & $\begin{array}{l}\text { Reviewed big data analytics and pro- } \\
\text { vide future research directions of big } \\
\text { data analytics }\end{array}$ & $\begin{array}{l}\text { Trust, privacy, and information security } \\
\text { can be further explained by utilizing } \\
\text { the characteristics of big data and } \\
\text { cognitive computing }\end{array}$ \\
\hline
\end{tabular}

an individual has acquired assurance and confidence in the information provided by the system [61]. Individual expectations towards technology build trust in its use. Typically, trust in use of technology is used to mitigate the uncertainty of mind when a person lacks experience and knowledge with using innovated technology and information 
systems [35]. Perceived trust is particularly important in the context of BDA, because adoption of a BDA system is a risk. Many studies have proved that perceived trust is a fundamental reason for the success or failure of information system adoption, including E-payment adoption [62], online purchasing [63], adoption of crypto currencies [64] and internet banking [65]. Trusting BDA is not the only issue, because mistrusting the capabilities of technology to deliver valuable services without interruption and data loss also reduce its adoption intentions [66]. Thus, based on the above cited literature, we assume that perceived trust will also affect BDA adoption.

H1 Perceived trust has a significant relationship with BIs to use BDA.

\section{Perceived security}

Perceived security refers to the degree to which a person believes that use of a specific system is safe and sound for transmitting and recording sensitive information [31, 61]. Perceived security of information is an important concern for healthcare, which contains sensitive patient information [39]. Perceived security is the factor that restricts user thinking about the benefits of a system and convinces him to use a system that is negatively perceived [40]. In the previous literature, many studies described the value of perceived security for the adoption of different analytical information systems (i.e., cloud computing [67], B2C electronic commerce [68], online markets [69], and electronic health record systems [70]). The use of BDA systems has some reservations in the minds of users regarding information security in the form of informational fraud, misuse of sensitive information and use by various unconcerned departments [71, 72]. Prior literature on BDA and its adoption has not emphasized security of information sufficiently $[72,73]$. Based on the prior literature, one key feature that can affect BDA adoption by healthcare organizations is the security of the analytical tools used to generate useful information. Employees' perceptions of the security level of technology possibly affect its adoption rate. Organizations that have high-level capabilities for dealing with information security will possibly develop the intention to use BDA.

H2 Perceived security has a significant relationship with BIs to use BDA.

\section{Task-technology fit}

The effective adoption of an information system relies on identification of the task for which the technology is used and whether a suitable match exists between the task and technology. As described by Goodhue [25], decomposition of TTF investigates the user's requirements for the information system, which ultimately impact the individual performance. The study of Lin and Huang [74] defines the task as activities performed to create valued outputs that satisfy human wants. Technology refers to the combination of various supportive activities to perform such tasks (i.e., computers, software, and others).

Prior studies by Benford, D'Ambra and Khan et al. [50, 75] described the various dimensions of tasks (e.g., nonroutines, interdependence, data access, and quantitative data analysis), which were related to several technical aspects that fulfilled individuals' needs. Task and technology both have significant impacts on the ability of TTF to estimate users' 
performances from several perspectives [76]. Innovative information technology and the system will be useless if they fail to satisfy individual requirements for performance of a specific task [27]. Therefore, recognizing the task-technology fit of a BDA system is significant, because it leads towards adoption of the system by healthcare organizations.

Prior studies discussed TTF in several aspects to determine the user task fitness for technology and group decision making, which led towards the successful adoption of an information system in various organizational settings (i.e., massive open online courses [MOOCs] [77], E-commerce [78], electronic health records [79], group decision support systems [80], high-speed data services [81], and mobile banking [27]). Therefore, based on the abovementioned literature, we believe that successful adoption of BDA by healthcare organizations significantly depends on matching of technology with the user task requirements, which has not been studied by prior researchers. The study of Zhou et al. [27] designed a TTF measure that could evaluate the fit between task and technology [79], with no need to evaluate the impact of the task and technology characteristics on TTF. Therefore, we use only TTF as used by Klopping and Qiwei [78, 79], and we use the task and technology characteristics separately.

H3 TTF has a significant relationship with BIs to use BDA.

\section{Technology acceptance model}

This paper applied the TAM to observe the adoption of BDA because it satisfactorily determined users' perceptions of the ease of use and usefulness of a new system [82]. TAM model determinants are optimal for determining user perceptions about its adoption [54]. TAM has been adopted by many researchers to successfully check and manage new system adoptions [54, 57, 83, 84]. Since the invention of TAM, an abundance of studies have produced different research models to effectively predict user attitudes and behavioral intentions towards technology adoption. Interestingly, all of these studies used approximately similar attributes to evaluate technology adoption [85]. Many studies have concluded that TAM is one of the best models in different contexts (e.g., forecasting general buyer behavioral intentions [86], telemedicine adoption [87] and radio frequency identification (RFID) integrated system adoption [85]). Previous literature has witnessed the adoption of innovations with massive implementation of TAM in the evaluation of user intentions regarding new technology diffusion [88]. The literature widely backs the use of TAM constructs [i.e., perceived usefulness (PU) and perceived ease of use (PEOU)] in measuring adoption solutions for new technology [24, 39, 89, 90].

The study proposes that TAM will provide superior understanding of BDA adoption, because BDA is a heavily technology-driven research area that is also user-oriented and innovation-focused [23]. Previous studies by Esteves, Rahman, and Shin [21, 23, 91] also concluded that TAM constructs (i.e., PEOU and PU) were significant predictors of BDA adoption/usage.

\section{Perceived ease of use}

The study of Davis [82] defined PEOU as the degree of ease involved when using an information system. Subsequently, Soon [54] clarified that ease in using the information system and technology would help enhance its acceptability among users. The use of an 
effortless system will help enhance individual and organizational performances [24, 92]. BDA potentially generates benefits for organizations, including cutting costs, controlling risk factors and helping with efficient decision making. Adoption of BDA depends on user considerations in terms of its convenience of use, which employs processing of large-scale and heterogeneous data [23]. However, the intensity of difficulty and ease of using BDA vary from person to person.

The prior literature has proven the existence of a significant direct relationship between the PEOU and a user's intentional behavior to adopt the system in various fields of study [54, 93, 94]; this relationship was also discussed by Esteves, Shin, and Weerakkody $[21,23,39]$ when studying user intentional behaviors regarding the adoption of big data, although these studies were less focused on this study context. For example, measuring the relationship of PEOU with the intention to use BDA is essential for healthcare organizations. The idea of BDA is not much older and can create much confusion in the user's mind about its ease of use, which may decrease user intentions towards its use in healthcare organizations.

Based on the aforesaid opinion, we propose the following hypothesis.

H4 PEOU has a significant relationship with BIs to use BDA.

\section{Perceived usefulness}

PU can be defined as whether an individual considers that their job performance will be improved by using the system [24, 82]. PU is the most commonly used variable and the primary driver of technology adoption [92, 95]; PU is also expected to be the primary driver of intention to use BDA in healthcare in this study. PU is an essential variable for studies of the adoption intentions of innovation from the user's perspective [54]. The previous literature has provided evidence of a positive relationship with intention to use many times, which has been successfully measured in various fields [26, 54, 94], including the field of big data $[21,23,57]$, but BDA not has not been a focus in healthcare.

The user cannot shape a positive perception of usefulness until he or she feels any practical worth of BDA in healthcare organizations. According to the theoretical principle of the TAM model, the study hypothesized that PU had a positive relationship with BIs.

H5 PU has a significant relationship with BIs to use BDA.

\section{Behavioral intention to use}

A BI is an intention to achieve some specified future behavior [21] and is a key predictor of an individual's actual use of technology $[96,97]$. BI is an essential first step towards actual adoption of any system [24]. According to Venkatesh and Davis [92], BI was an important mediator in the relationship between predictors and specific system adoption. The prior literature has proven that a person is more likely to adopt a technology if he has an intention to use it [98]. The social sciences literature has provided evidence that BIs have a direct impact on actual use [77, 82], and various studies have concluded that BIs have a significant influence on adoption of BDA [21, 23]. This study suggests that individuals with the intention to use BDA will lead to the actual use of BDA. 
H6 BIs have a significant relationship with actual use of BDA.

\section{The moderating role of resistance to change}

According to French [99], change is a state in which differences exist between new and old ways of thinking. The behavior of individuals who protects them from the consequences of either real or imagined change is called RTC [100]. Oliver [101] defines RTC as protection of the status quo via individuals creating resistance against the innovative system. Every innovative system is commonly a source of panic and bears RTC due to its perception as a possible threat to the solidity of old habits [43, 101]. To avoid RTC in organizations when implementing new systems or ways of working, Oreg [102] proposed that the organization should encourage employees to learn new skills, tasks, and programs. One aspect of personality is that RTC is very important for technology adoption [103]. The previous literature has shown that RTC is a demotivator and negatively influences the acceptance of information technology [104-106].

The study of Alomari [107] concluded that RTC was one factor that caused non-adoption and failure of new information systems. Lallmahomed et al. [33] investigated the adoption behavior of an e-government system by focusing on RTC and established a significant negative relationship between RTC and adoption of the system. Many other researchers also proved the importance and negative associations of RTC with acceptance of information and communication technology systems [42, 43, 108]. A study of green supply chain management (GSCM) adoption [41] investigated RTC as a moderator between BIs and adoption of GSCM and concluded that higher RTC among employees would lead to non-implementation of GSCM. Similarly, Bral III et al. [109] investigated the moderating role of RTC between psychological capital and organizational citizenship behavior. Regarding BDA in healthcare organizations, RTC is likely to moderate between intentional behaviors and actual usage of the BDA system by employees. The previous literature also reported that RTC either did not significantly affect or had a minor direct impact on the actual use of technology $[41,109]$. Therefore, this study also focuses on the moderating role of RTC rather than on the direct influence of RTC on actual use.

The American Health and Human Services Department faced huge resistance to change from physicians when they were adopting an electronic health records system, especially during the initial phase [110]. The study of Bhattacherjee [111] empirically investigated and concluded that RTC was a key barrier to actual adoption of information technology in the healthcare sector in both the initial and post-adoption phases but was more of an obstacle during the initial phase. Other researchers also found that RTC was often regarded as the cause of failure of the actual use of information technology in healthcare organizations $[112,113]$. Here, we focus on RTC because we also investigate the initial adoption of BDA. However, although RTC has a key impact on the adoption of information systems in healthcare, previous research has not paid attention to RTC during this process. Therefore, to bridge this big gap in the literature, we considered the following hypothesis:

H7 RTC moderates the relationship between BIs to use and actual use of BDA. 


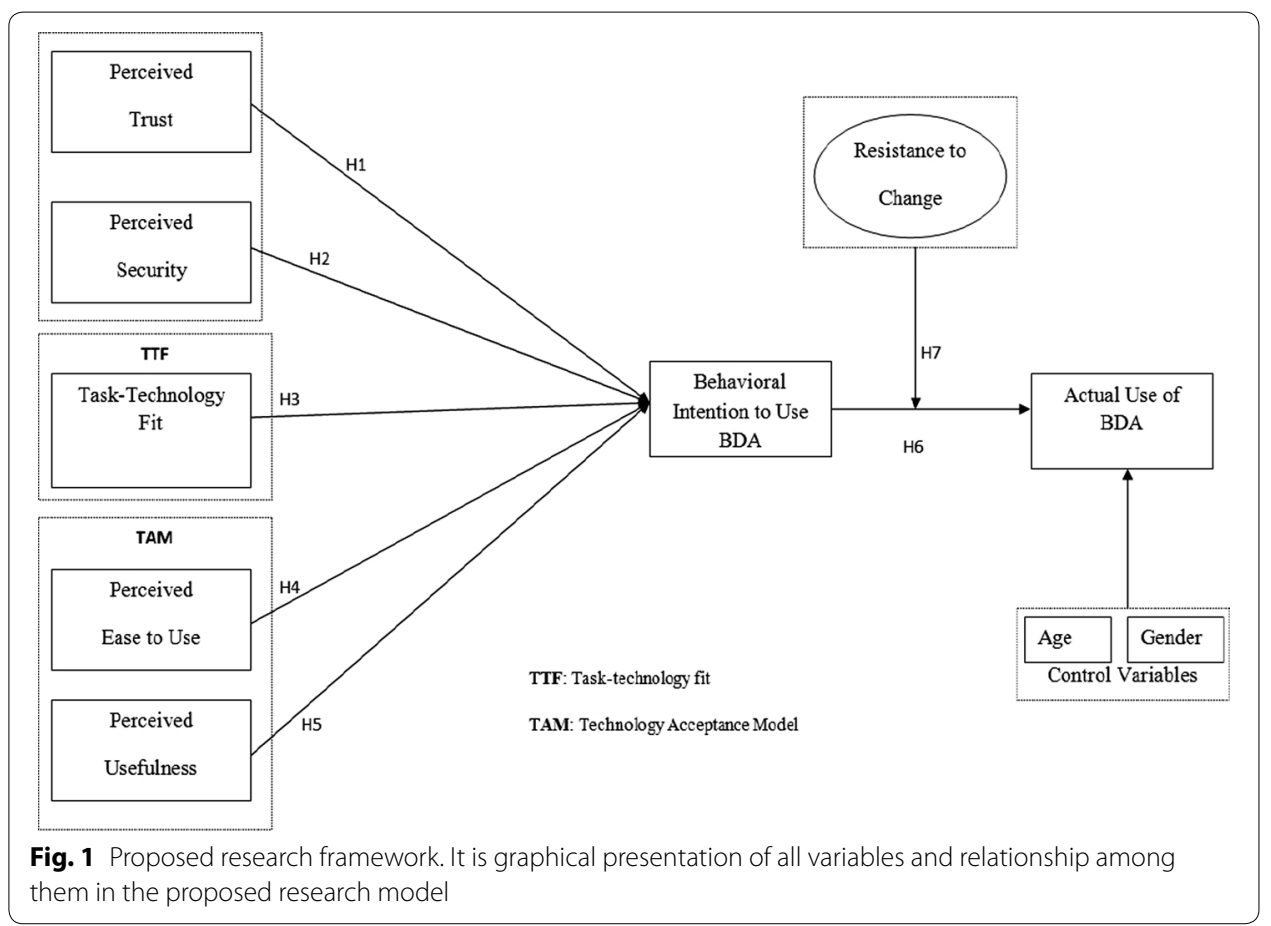

\section{Methodology}

Here, the researchers describe the methodology followed by this study. Figure 2 represents the flow diagram of the research progress.

\section{Development of measures}

In this study, we adopted all of the measures from previous studies with the same context to preserve the content validity. All constructs were measured on a 7-point Likert scale in which the agreement of the participants to a given statement was assigned a score ranging from 1 (strongly disagree) to 7 (strongly agree). The 3 -item perceived trust scale was adapted from [114], the four-item perceived security scale was adapted from [31], and the three-item task-technology fit scale was adapted from [27, 74]. Similarly, the three-item scales for both PU and PEOU were adapted from [39]. The three-item scale for BI to use was adapted from [98], and the three-item scale for actual use was adapted from [98]. The four-item scale for RTC was adapted from [104].

\section{Sampling and data collection}

The structured questionnaire-based survey method was used in this empirical study to measure the proposed model. The survey method is helpful for measurement of behaviors and the relationships among constructs [115]. Typically, the survey method has been used in previous studies in which researchers assess adoption or user intention-behavior [116]. First, a pilot study was conducted with 20 prospective users of the BDA system. The results of the pilot study were discussed with four senior professors with great command of construct building, and then the measurement items were refined based on the discussions, which also confirmed the face validity of the measurement scale. All 


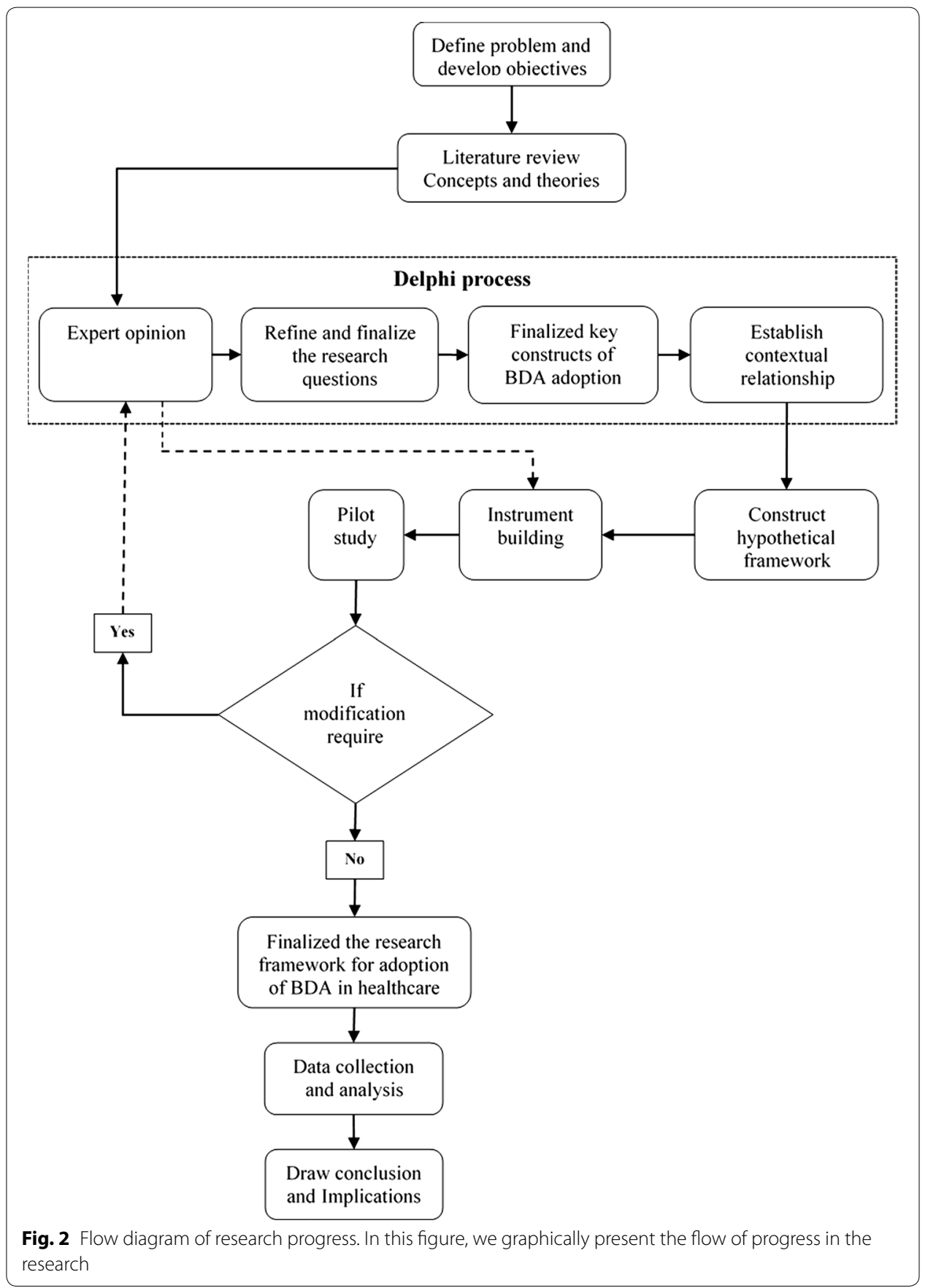

prospective BDA system end users from 25 hospitals in four big cities of Punjab Pakistan (Lahore, Faisalabad, Rawalpindi, and Multan) and the Islamabad capital territory of Pakistan were selected for data collection using a convenience sampling technique. A convenience sampling technique is a suitable sampling technique by virtue of the accessibility of the researcher to the participants [117]. A refined questionnaire with a cover letter that assured the respondents that the data would be used only for academic research purposes and kept confidential was distributed to all participants through an online survey. The online survey ensures research consistency with data collection [118]. 
A total of 400 questionnaires were distributed among the participants, and 260 filled questionnaires were received, of which 36 questionnaires that contained missing values or biased responses were not included in the study. The remaining 224 responses were selected for the analysis. Furthermore, the study considered age and gender as control variables to ensure that the results of the model were not influenced adversely by covariance, because the previous literature suggested that age and gender might influence the intention to use $[63,118]$.

\section{Results and discussion}

We employed structural equation modeling (SEM) using the IBM-AMOS (v21) software to evaluate the proposed research model. It is evident from the previous literature that the AMOS software is a powerful tool for performing confirmatory factor analysis (CFA) and SEM [119]. AMOS is also a complete package for evaluation of formative measures and moderating relationships [120]. Because AMOS is user-friendly and provides a graphical interface that enables easier handling, we used this software for the CFA and SEM and SPSS (v 21) to measure the validity and reliability and conduct an exploratory factor analysis (EFA) prior to the CFA and SEM. We also used SPSS for the demographic statistics. Table 2 presents the demographic information for the respondents, of whom 128 out of 224 were male, $82 \%$ were in the age bracket of $25-45$ years, and $98 \%$ had a bachelor's or higher degree; the remaining $2 \%$ had a high school certificate or relevant diploma as well as knowledge and experience with using technological systems.

\section{Measurement model}

Kaiser-Meyer-Olkin (KMO) and Bartlett's test of sphericity were used to measure sample adequacy [121]. The KMO value was 0.857 , which was within the cutoff range of $0.8-1$ that showed sample adequacy. Data were collected without regard to differences in time; we checked the common method bias (CMB) in the data using Harman's singlefactor test [122]. After categorizing the items into eight subgroups, the results indicated that the first factor explained $31.1 \%$ of the variance, which was below the $40 \%$ cutoff rate. Thus, CMB is not an issue in the study.

Prior to the path analysis, the reliability and validity were measured. The value of Cronbach's alpha was greater than 0.7 for all factors. The composite reliability (CR) and AVE values ranged from 0.847 to 0.962 and from 0.652 to 0.864 , respectively, which were within the accepted ranges $[123,124]$. Table 3 shows all of the Cronbach's alpha, $\mathrm{CR}$ and AVE values. Table 4 proves that no issue existed with the discriminant validity of the constructs in the study, because the square root of AVE was higher than all interconstruct correlations [125]. The study conducted EFA using SPSS to ensure that the measures in the study were correct with respect to the concerned variables. The factor loading values shown in Table 3 ranged from 0.744 to 0.953 , which proved that no issue existed regarding cross loading of the constructs [126].

CFA was conducted through AMOS to check the consistency and validity of the constructs for the proposed study framework. The CFA values are CMIN/DF $=1.545$, root mean square error of approximation (RMSEA) $=0.049$ with a PCLOSE value of 0.529 , comparative fit index $(\mathrm{CFI})=0.967$ and Tucker-Lewis fit index $(\mathrm{TLI})=0.960$. All values 
Table 2 Demographical information of respondents

\begin{tabular}{lcc}
\hline Category & Frequency & Percentage (\%) \\
\hline Gender & 128 & \\
Male & 96 & 57.1 \\
Female & 224 & 42.9 \\
Total & & 100.0 \\
Age & 29 & \\
$18-25$ & 89 & 12.9 \\
$25-35$ & 94 & 39.7 \\
$35-45$ & 12 & 42.0 \\
45 and above & 224 & 5.4 \\
Total & & 100.0 \\
Education & 4 & \\
High school/diploma & 109 & 1.8 \\
Bachelor & 101 & 48.7 \\
Master & 10 & 45.1 \\
Doctoral & 224 & 4.5 \\
Total & & 100.0 \\
\hline
\end{tabular}

are in accordance with the threshold values [126]. These results proved the good fitness of the model.

\section{Structural model}

The above results proved good fitness of the model and that the data were highly reliable and valid. Therefore, we continued with the path analysis. In the path analysis, $\mathrm{CMIN} / \mathrm{DF}=1.748$, RMSEA $=0.058$ with a PCLOSE value of $0.278, \mathrm{CFI}=0.939$, and $T L I=0.901$, which proved that the model was a good fit. Then, the study measured the path coefficients and found that all coefficients were significant. The results shown in Fig. 3 demonstrate that perceived trust $(\beta=0.124, p<0.05)$, perceived security $(\beta=0.209, \mathrm{p}<0.001)$, TTF $(\beta=0.263, \mathrm{p}<0.001)$, PEOU $(\beta=0.240, \mathrm{p}<0.001)$, and PU $(\beta=0.118, p<0.05)$ have significant positive relationships with BIs to use BDA. Thus, H1, H2, H3, H4, and $\mathrm{H} 5$ are supported. In addition, BIs to use BDA ( $\beta=0.412$, $\mathrm{p}<0.001$ ) have a significant positive relationship with the actual use of BDA, and thus H6 is also accepted. The model also demonstrates that $45 \%$ of the variance exists in the BIs to use BDA and $25 \%$ of the variance represents the actual use of BDA. The control variables age and gender did not have a significant relationship with the actual use of BDA. Therefore, we concluded that the hypothesized study model was accepted.

\section{Moderating the effect of RTC}

The study proved that RTC moderated the relationship between BIs to use the BDA system and actual use of the BDA system. The interaction term (behavioral intentions to use $\times$ resistance to change $)(\beta=-0.201, p<0.001)$ had a significant and negative effect on the actual use of the BDA system. Thus, a higher RTC weakened the relationship between BIs to use and actual use of the BDA system, which accepted H7. 
Table 3 Results of factor loadings, validity, and reliability

\begin{tabular}{|c|c|c|c|c|c|}
\hline Variables & Items & Loadings & Cronbach's alpha & CR & AVE \\
\hline \multirow[t]{3}{*}{ Perceived trust } & PT1 & 0.849 & 0.834 & 0.847 & 0.654 \\
\hline & PT2 & 0.879 & & & \\
\hline & PT3 & 0.778 & & & \\
\hline \multirow[t]{4}{*}{ Perceived security } & PS1 & 0.838 & 0.903 & 0.905 & 0.705 \\
\hline & PS2 & 0.849 & & & \\
\hline & PS3 & 0.806 & & & \\
\hline & PS4 & 0.744 & & & \\
\hline \multirow[t]{3}{*}{ Task-technology fit } & TTF1 & 0.864 & 0.898 & 0.900 & 0.751 \\
\hline & TTF2 & 0.797 & & & \\
\hline & TTF3 & 0.768 & & & \\
\hline \multirow[t]{3}{*}{ Perceived ease of use } & PEOU1 & 0.857 & 0.877 & 0.877 & 0.704 \\
\hline & PEOU2 & 0.859 & & & \\
\hline & PEOU3 & 0.805 & & & \\
\hline \multirow[t]{3}{*}{ perceived usefulness } & PU1 & 0.816 & 0.838 & 0.847 & 0.652 \\
\hline & PU2 & 0.881 & & & \\
\hline & PU3 & 0.841 & & & \\
\hline \multirow[t]{3}{*}{ Behavioral intention to use BDA } & $\mathrm{Bl1}$ & 0.778 & 0.909 & 0.911 & 0.773 \\
\hline & $\mathrm{Bl} 2$ & 0.796 & & & \\
\hline & $\mathrm{Bl} 3$ & 0.809 & & & \\
\hline \multirow[t]{4}{*}{ Resistance to change } & RTC1 & 0.939 & 0.962 & 0.962 & 0.864 \\
\hline & RTC2 & 0.937 & & & \\
\hline & RTC3 & 0.953 & & & \\
\hline & RTC4 & 0.944 & & & \\
\hline \multirow[t]{3}{*}{ Actual use of BDA } & AU1 & 0.872 & 0.918 & 0.919 & 0.792 \\
\hline & AU2 & 0.889 & & & \\
\hline & AU3 & 0.879 & & & \\
\hline
\end{tabular}

Table 4 Correlations matrix and square root of AVE

\begin{tabular}{lclllllll}
\hline & RTC & PS & AU & PEOU & TTF & PT & PU & IB \\
\hline RTC & 0.929 & & & & & & \\
PS & 0.092 & 0.840 & & & & & \\
AU & $0.168^{*}$ & $0.396^{* * *}$ & 0.890 & & & & \\
PEOU & 0.111 & $0.433^{* * *}$ & $0.403^{* * *}$ & 0.839 & & & \\
TTF & -0.002 & $0.619^{* * *}$ & $0.429^{* * *}$ & $0.448^{* * *}$ & 0.866 & & \\
PT & -0.041 & $0.413^{* * *}$ & 0.075 & $0.152^{*}$ & $0.357^{* * *}$ & 0.809 & \\
PU & -0.034 & $0.291^{* * *}$ & 0.047 & $0.270^{* * *}$ & $0.258^{* * *}$ & $0.337^{* * *}$ & 0.808 & \\
IB & 0.004 & $0.556^{* * *}$ & $0.490^{* * *}$ & $0.524^{* * *}$ & $0.616^{* * *}$ & $0.370^{* * *}$ & $0.348^{* * *}$ & 0.879 \\
\hline
\end{tabular}

Inclined italic lines represent the square root of the AVE of each variable

Significance of correlations: ${ }^{*} p<0.050,{ }^{* *} p<0.010,{ }^{* * *} p<0.001$

BDA change the decision-making style in the healthcare sector. An interactive and task-oriented system can make possible use of BDA in any sector, especially in healthcare organizations. With these objectives in mind, this study provided useful findings and a framework for practical adoption of BDA systems and future research. The study focused on security and trust of information, which were observed to be big concerns of system users. Similar to the results of [23], perceived trust and perceived security had a 


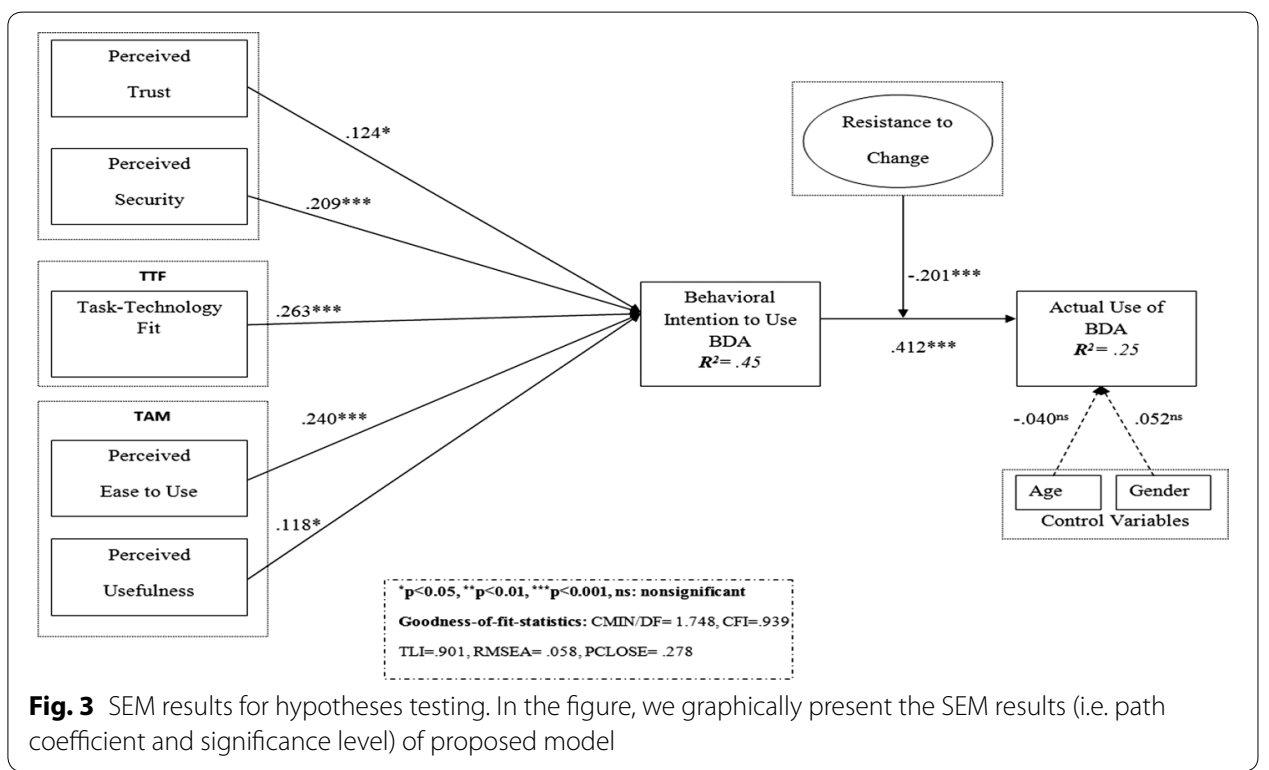

positive effect on BIs to adopt BDA. The study also investigated TTF, which had a positive impact on the behavioral intentions to adopt BDA, indicating that features of the system must be matched to the specific task of the user for successful adoption of a BDA system. Our results are consistent with the results of Afshan and Brock [127]. Similar to previous studies by Shin and Soon et al. [23] concerning BDA adoption, this study also demonstrated the positive effects of PEOU and PU on BIs to adopt BDA, which suggested that the system should be easy to use and have attractive features that make it look useful to the user. Furthermore, the study investigated RTC in employees, which played a key role in the convergence of BIs to put the system into actual use. The results of this study illustrate that as RTC from employees increases, actual use of BDA systems will decrease. The RTC result is consistent with that of Beal III and Nejati [41, 109].

\section{Conclusion}

The adoption of BDA is in the initial stage, in which many healthcare organizations are thinking about adopting BDA systems. The present is an optimal time to adopt/implement BDA systems, especially in healthcare organizations, with an aim of providing better healthcare facilities by maintaining patients' health records and formulating better strategies. This study contributes to the literature by showing the main factors that are important when adopting the BDA system. This study results are also imperative for strategy makers who want to implement a BDA system by demonstrating factors that are important initially. In contrast to existing studies, this study also expressed the huge positive combined effect of the TTF and TAM theories on behavioral intentions to adopt BDA. Combining TAM and TTF gives more effective results than use of TAM or TTF individually $[19,26]$. The prior literature demonstrates use of the TAM model alone in the adoption of a BDA system. The current study also incorporated important concerns from users regarding adoption of any innovative system, such as perceived security and perceived trust. These factors provide an additional significant aspect to the literature regarding BDA. Our sampling territory is Pakistan, which 
is a developing country. RTC is the largest barrier in the adoption of innovative systems, particularly in developing countries but also in developed countries. According to our best information, this study is the first to enrich the literature by linking resistance to change of employees with BDA adoption as a moderator. This moderation result will help implementers control this factor at the time of adopting the BDA system.

\section{Theoretical contribution}

This study contributes noteworthy research insights into BDA system implementation. The study fills the main gap in the literature concerning the empirical evidence for BDA in Pakistani healthcare organizations for the first time. Second, the majority of previous studies only highlighted the importance, challenges, and opportunities of BDA, because BDA was in the initial stage of adoption and was a comparatively new topic. Second, few researchers have investigated the adoption of BDA, and the existing studies have focused on a specific perspective (i.e., an economic or financial perspective) or have simply emphasized TAM theory. This study is probably the first on BDA adoption to propose a model that combines the TAM and TTF theories as predictors of behavioral intentions to use BDA. Thus, integration and implementation of the TAM theory with the TTF theory for BDA adoption is a new perspective that enhances the literature. Second, to switch from the previous healthcare system to a BDA system, the literature needs a strong theoretical basis for further research and a broad and general research model that is not specific to one aspect of the business. This study model will be helpful and will advance a theory for future BDA research. Furthermore, the study included security and trust aspects of information in the model to elucidate their impacts on BI. Our results will contribute to the security and trust perspectives in the technology acceptance literature and provide security and trust grounds for further research. In addition, the results obtained for resistance to change represent an immense theoretical contribution for researchers, because the current study has highlighted this important barrier in the implementation of BDA. This investigation can be used as a reference for future research and to increase understanding of the adoption of BDA research.

\section{Practical contribution}

The study also contributed practically in several ways similar to its theoretical contributions. The findings of the study propose salient guidelines and important implications for practitioners and implementers of BDA systems that can assist with successful adoption of BDA systems. First, connecting system functions with the required tasks of the organization as well as the PU and PEOU of the system are important. This approach will provide results that are more fruitful for practitioners when implementing BDA systems. Second, the findings of the study also indicate that perceived security and perceived trust are the key predictors of intentions regarding acceptance of a BDA system. Third, this study explores the moderating effect of RTC, which reduces the adoption of BDA systems in developing countries. This study will provide broad insights for implementers of BDA systems in developing countries and allow the design of strategies to ultimately reduce employees' resistance levels. Finally, this study provides an initial platform for practitioners for adoption and promotion of BDA practices within the organization to obtain maximum advantages of innovative technology, especially in developing countries. 


\section{Limitations and future directions}

The authors acknowledge some limitations of the current study. First, the focus of this study is on healthcare organizations in Pakistan regarding adoption of a BDA system. The impact of organizational culture was ignored by this study, which might have an effect on the level of adoption of this system. Future researchers may test the same research model in other organizations considering different cultural setups, because the organizational setup and culture vary from industry to industry; therefore, the findings of this study may vary when applied to different sector organizations. This study provided understanding of BDA system adoption in developing countries in particular and developed countries in general. Thus, future researchers can test this model in developed countries to increase the generalization of the study, because the severity of resistance to change from employees is greater in developing than in developed countries [41]. The research model can be tested in different cultural settings with a focus on adoption of BDA systems. This study was aimed to investigate the user adoption factors of BDA, which neglect the other side of system implementation. Therefore, future researchers can identify the developers/architects intentions for development and implementation of BDA system. Finally, this study was based on cross-sectional settings, which restricted measurement of the consistency in respondent behavior; this gap should be tested in a longitudinal setup to improve the significant contribution to knowledge.

\section{Abbreviations}

BDA: big data analytics; TTF: task-technology fit; TAM: technology acceptance model; PEOU: perceived ease of use; PU: perceived usefulness; RTC: resistance to change; Bl: behavioral intentions.

\section{Authors' contributions}

MS conceptualized the idea, prepared the literature and build theory, designed research framework and collect data, analyzed results, drafted and proof-read the manuscript, GCY and ZL provided supervision and guide throughout the process. FS and $\mathrm{YH}$ contribute in analysis and results writing. All authors read and approved the final manuscript.

Acknowledgements

This study has been supported by "National Natural Science Foundation of China (NSFC)" Grant Numbers: 71774044, 71672050 , and 71272191 .

Competing interests

The authors declare that they have no competing interests.

Availability of data and materials

Data can be available on demand.

Consent for publication

We, the authors, consent to the publication of this manuscript in the Journal of Big Data.

Ethics approval and consent to participate

Not applicable.

Funding

Not applicable.

\section{Publisher's Note}

Springer Nature remains neutral with regard to jurisdictional claims in published maps and institutional affiliations.

Received: 22 October 2018 Accepted: 8 January 2019

Published online: 31 January 2019

\section{References}

1. Müller O, Junglas I, Vom Brocke J, Debortoli S. Utilizing big data analytics for information systems research: challenges, promises and guidelines. Eur J Inf Syst. 2016;25:289-302. 
2. Cottle M, Hoover W. Transforming health care through big data. Washington DC: Institute for Health Technology Transformation; 2013. p. 6-19.

3. Lavalle S, Lesser E, Shockley R, Hopkins MS, Kruschwitz N. Big data, analytics and the path from insights to value. MIT Sloan Manag Rev. 2011;52:21-32.

4. Raghupathi W, Raghupathi V. Big data analytics in healthcare: promise and potential. Health Inf Sci Syst. 2014;2:3. https://doi.org/10.1186/2047-2501-2-3.

5. Nannetti P. The deciding factor : big data \& decision making. Capgemini Consulting Technology outsourcing. 2012;1-5. https://www.capgemini.com/resources/the-deciding-factor-big-data-decision-making/.

6. Connolly S, Wooledge S. Harnessing the value of big data analytics. Big DataAnalytics. 2012; p. 1-14.

7. Wang Y, Hajli N. Exploring the path to big data analytics success in healthcare. J Bus Res. 2017;70:287-99.

8. Maria VMF. Big data services based on mobile data and their strategic importance. In: 7th International Conference on Computers Communications and Control. 2018;276-81. http://ieeexplore.ieee.org/lpdocs/epic03/wrapp er.htm?arnumber $=6758026$.

9. Sandhya Kumari S, Sandhya Rani K. Big data analytics for healthcare system. In: 2018 IADS international conference on computing, communications \& data engineering (CCODE), 7-8 February 2018.

10. Gharajeh MS. Biological big data analytics. Adv Comput. 2018;109:321-55.

11. Wang Y, Kung LA, Byrd TA. Big data analytics: understanding its capabilities and potential benefits for healthcare organizations. Technol Forecast Soc Change. 2018;126:3-13.

12. Groves P, Knott D. The 'big data' revolution in healthcare. New York: McKinsey \& Company; 2013.

13. Kim MK, Park JH. Identifying and prioritizing critical factors for promoting the implementation and usage of big data in healthcare. Inf Dev. 2017;33:257-69.

14. Braunstein ML. Practitioner's guide to health informatics. Switzerland: Springer International Publishing; 2015. p. 133-49. https://doi.org/10.1007/978-3-319-17662-8.

15. Huang T, Lan L, Fang X, An P, Min J, Wang F. Promises and challenges of big data computing in health sciences. Big Data Res. 2015;2:2-11.

16. Kim MK, Cho YW, Park JH. The prospects and development directions for healthcare big data industry. Electronics and Telecommunications Research Institute. 2013.

17. Heitmueller A, Henderson S, Warburton W, Elmagarmid A, Pentland AS, Darzi A. Developing public policy to advance the use of big data in health care. Health Aff (Millwood). 2014;33:1523-30.

18. Bughin J. Reaping the benefits of big data in telecom. J Big Data. 2016;3:14.

19. Dishaw MT, Strong DM. Extending the technology acceptance model with task-technology fit constructs. Inf Manag. 1999;36:9-21.

20. Petersen Glen S. High impact sales force automation. Boca Raton: FL St Lucie Press; 1997.

21. Esteves J, Curto J. A risk and benefits behavioral model to assess intentions to adopt big data. J Intell Stud Bus. 2013;3:37-46. https://www.scopus.com/inward/record.uri?eid=2-s2.0-84905689717\&partnerlD=40\&md5=53271 4767e19a3335cb1 ef08de04d66c.

22. Rahman N. Factors affecting big data technology adoption. Student Res Symp 2016. 2016;0-29. http://pdxscholar library.pdx.edu/studentsymposium\%5Cn, http://pdxscholar.library.pdx.edu/studentsymposium/2016/Presentati ons/10.

23. Shin DH. Demystifying big data: anatomy of big data developmental process. Telecomm Policy. 2016;40:837-54.

24. Brock V, Khan HU. Big data analytics: does organizational factor matters impact technology acceptance? J Big Data. 2017:4:21.

25. Goodhue DL, Thompson RL. Task-technology fit and individual performance. MIS Q. 1995;19:213. http://www.jstor .org/stable/249689? origin=crossref.

26. Wu B, Chen X. Continuance intention to use MOOCs: integrating the technology acceptance model (TAM) and task technology fit (TTF) model. Comput Human Behav. 2017:67:221-32.

27. Zhou T, LuY, Wang B. Integrating TTF and UTAUT to explain mobile banking user adoption. Comput Human Behav. 2010;26:760-7.

28. Junglas IA, Watson RT. Location-based services. Commun ACM. 2008;51:65-9. http://portal.acm.org/citation cfm?doid $=1325555.1325568$.

29. Lee $\mathrm{C}-\mathrm{C}$, Cheng HK, Cheng H-H, Cheng HK. An empirical study of mobile commerce in insurance industry: tasktechnology fit and individual differences. Decis Support Syst. 2007;43:95-110. www.elsevier.com/locate/dss.

30. Damghanian $\mathrm{H}$, Zarei A, Siahsarani Kojuri MA. Impact of perceived security on trust, perceived risk, and acceptance of online banking in Iran. J Internet Commer. 2016;15:214-38.

31. Arpaci I, Yardimci Cetin Y, Turetken O. Impact of perceived security on organizational adoption of smartphones. Cyberpsychol Behav Soc Netw. 2015;18:602-8. https://doi.org/10.1089/cyber.2015.0243.

32. Fife E, Orjuela J. The privacy calculus: mobile apps and user perceptions of privacy and security. Int J Eng Bus Manag. 2012:4:1-10.

33. Lallmahomed MZI, Lallmahomed N, Lallmahomed GM. Factors influencing the adoption of e-government services in Mauritius. Telemat Inform. 2017;34:57-72.

34. Wang EST, Lin RL. Perceived quality factors of location-based apps on trust, perceived privacy risk, and continuous usage intention. Behav Inf Technol. 2017:36:2-10.

35. Liao C, Liu C-C, Chen K. Examining the impact of privacy, trust and risk perceptions beyond monetary transactions: An integrated model. Electron Commer Res Appl. 2011;10:702-15. http://linkinghub.elsevier.com/retrieve/ pii/S1567422311000408.

36. Nguyen T, Zhou L, Spiegler V, leromonachou P, Lin Y. Big data analytics in supply chain management: a state-ofthe-art literature review. Comput Oper Res. 2018;98:254-64. https://doi.org/10.1016/j.cor.2017.07.004.

37. Jain P, Gyanchandani M, Khare N. Big data privacy: a technological perspective and review. J Big Data. 2016;3:25.

38. Heart T. Who is out there? Exploring the effects of trust and perceived risk on SaaS adoption intentions. DATA BASE Adv Inf Syst. 2010:41:49-67. 
39. Sivarajah U, Kamal MM, Irani Z, Weerakkody V. Critical analysis of big data challenges and analytical methods. J Bus Res. 2017;70:263-86.

40. Malaka I, Brown I. Challenges to the organisational adoption of big data analytics : a case study in the South African telecommunications industry. In: Proceedings of the 2015 Annual Research Conference on South African Institute of Computer Scientists and Information Technologists. 2015; p. 27.

41. Nejati M, Rabiei S, Chiappetta Jabbour CJ. Envisioning the invisible: understanding the synergy between green human resource management and green supply chain management in manufacturing firms in Iran in light of the moderating effect of employees' resistance to change. J Clean Prod. 2017;168:163-72.

42. Sharma M, Gupta R, Acharya P. Prioritizing the critical factors of cloud computing adoption using multi-criteria decision-making techniques. Glob Bus Rev. 2017. https://doi.org/10.1177/0972150917741187.

43. Reginato E, Fadda I, Paglietti P. The influence of resistance to change on public-sector reform implementation: the case of Italian municipalities'internal control system. Int J Public Adm. 2016;39:989-99.

44. Lorenzi NM, Kouroubali A, Detmer DE, Bloomrosen M. How to successfully select and implement electronic health records. BMC Med Inform Decis Mak. 2009;9:15. http://uvic.summon.serialssolutions.com/2.0.0/link/0/eLvHC XMwY2BQsEg1TgWd_JSaZGGWbJ6anGhgnmRqap5qamJmYpgE3iCG2DqGVJq7CTEwpeaJMsi6uYY4e-iCSsj4AsiZ C_GgU1yAlY2FoYEYA28iaPF3Xgl4k1gKAK4dG90.

45. Bates DW. Physicians and ambulatory electronic health records. Health Aff. 2005;24:1180-9.

46. Bartos CE, Butler BS, Crowley RS. Ranked levels of influence model: selecting influence techniques to minimize IT resistance. J Biomed Inform. 2011;44:497-504.

47. Guo X, Sun Y, Wang N, Peng Z, Yan Z. The dark side of elderly acceptance of preventive mobile health services in China. Electron Mark. 2013;23:49-61.

48. Groves P, Kayyali B, Knott D, Van Kuiken S. The "big data" revolution in healthcare: accelerating value and innovation. McKinsey Glob Inst. 2013;1-22. http://www.images-et-reseaux.com/sites/default/files/medias/blog/2013/12/ mckinsey_131204_-_the_big_data_revolution_in_healthcare.pdf.

49. Yan X, Song T, Wu Q. An improved cultural algorithm and its application in image matching. Multimed Tools Appl. 2017:76:14951-68.

50. Latif Z, Tunio MZ, Pathan ZH, Jianqiu Z, Ximei L, Sadozai SK. A review of policies concerning development of big data industry in Pakistan: Subtitle: Development of big data industry in Pakistan. In: 2018 international conference on computing, mathematics and engineering technologies (iCoMET), 2018; 2018; p. 1-5.

51. Mahmood T, Afzal U. Security analytics: big data analytics for cybersecurity. In: 2013 2nd national conference on Information assurance (ncia). 2013;129-34. http://ieeexplore.ieee.org/stamp/stamp.jsp?arnumber=6725337.

52. Tsai CW, Lai CF, Chao HC, Vasilakos AV. Big data analytics: a survey. J Big Data. 2015;2:21.

53. Archenaa J, Anita EAM. A survey of big data analytics in healthcare and government. Procedia Comput Sci. 2015;50:408-13.

54. Soon KWK, Lee CA, Boursier P. A study of the determinants affecting adoption of big data using integrated technology acceptance model (TAM) and diffusion of innovation (DOI) in Malaysia. Int J Appl Bus Econ Res. 2016;14:17-47.

55. LaBrie RC, Steinke GH, Li X, Cazier JA. Big data analytics sentiment: US-China reaction to data collection by business and government. Technol Forecast Soc Change. 2018;130:45-55.

56. Memon MA, Soomro S, Jumani AK, Kartio MA. Big data analytics and its applications. Ann Emerg Technol Comput. 2017;1. www.aetic.theiaer.org.

57. Weerakkody V, Kapoor K, Balta ME, Irani Z, Dwivedi YK. Factors influencing user acceptance of public sector big open data. Prod Plan Control. 2017;28:891-905.

58. Arunachalam D, Kumar N, Kawalek JP. Understanding big data analytics capabilities in supply chain management: unravelling the issues, challenges and implications for practice. Transp Res Part E Logist Transp Rev. 2018:114:416-36.

59. Gupta S, Kar AK, Baabdullah A, Al-Khowaiter WAA. Big data with cognitive computing: a review for the future. Int J Inf Manag. 2018;42:78-89.

60. Pavlou PA, Fygenson M. Understanding and prediction electronic commerce adoption: an extension of the theory of planned behavior. MIS Q. 2006;30:115-43. http://search.ebscohost.com/login.aspx?direc $\mathrm{t}=$ true \&db=buh\&AN=19754863\&site=ehost-live\%0A, http://www.jstor.org/stable/25148720.

61. Cui F, Lin D, Qu H. The impact of perceived security and consumer innovativeness on e-loyalty in online travel shopping. J Travel Tour Mark. 2018;35:819-34. https://doi.org/10.1080/10548408.2017.1422452.

62. Nguyen TD, Huynh PA. The roles of perceived risk and trust on e-payment adoption. In: International Econometric Conference of Vietnam. 2018; p. 926-40.

63. Fang Y, Qureshi I, Sun H, McCole P, Ramsey E, Lim KH. Trust, satisfaction, and online repurchase intention: the moderating role of perceived effectiveness of e-commerce institutional mechanisms. MIS Q. 2014;38:407-27. https://misq.org/trust-satisfaction-and-online-repurchase-intention-the-moderating-role-of-perceived-effectiven ess-of-e-commerce-institutional-mechanisms.html.

64. Shahzad F, Xiu GY, Wang J, Shahbaz M. An empirical investigation on the adoption of cryptocurrencies among the people of mainland China. Technol Soc. 2018. http://www.sciencedirect.com/science/article/pii/S0160791X18300204.

65. Kim KK, Prabhakar B, Park SK. Trust, perceived risk, and trusting behavior in internet banking. Asia Pacific J Inf Syst. 2009;19:1-23.

66. Alkhater $\mathrm{N}$, Walters R, Wills $\mathrm{G}$. An empirical study of factors influencing cloud adoption among private sector organisations. Telemat Inform. 2018;35:38-54. http://linkinghub.elsevier.com/retrieve/pii/S0736585317303088.

67. Ackermann T, Widjaja T, Benlian A, Buxmann P. Perceived IT security risks of cloud computing: conceptualization and scale development. ICIS. 2012;1-20. http://aisel.aisnet.org/icis2012/proceedings/ISSecurity/3/.

68. Hartono E, Holsapple CW, Kim KY, Na KS, Simpson JT. Measuring perceived security in B2C electronic commerce website usage: a respecification and validation. Decis Support Syst. 2014;62:11-21.

69. Mekovec R, Hutinski Ž. The role of perceived privacy and perceived security in online market. In: MIPRO, 2012 Proceedings of the 35th International Convention. 2012; p. 1883-8. 
70. Zandieh SO, Yoon-Flannery K, Kuperman GJ, Langsam DJ, Hyman D, Kaushal R. Challenges to EHR implementation in electronic-versus paper-based office practices. J Gen Intern Med. 2008;23:755-61.

71. Ferguson AG. Policing predictive policing. Wash Univ Law Rev. 2017;211-68. https://papers.ssrn.com/sol3/paper s.cfm?abstract_id=2765525.

72. Broeders D, Schrijvers E, van der Sloot B, van Brakel R, de Hoog J, Hirsch Ballin E. Big Data and security policies: towards a framework for regulating the phases of analytics and use of big data. Comput Law Secur Rev. 2017:33:309-23.

73. Abouelmehdi K, Beni-Hessane A, Khaloufi H. Big healthcare data: preserving security and privacy. J Big Data. 2018;5:1.

74. Lin TC, Huang CC. Understanding knowledge management system usage antecedents: an integration of social cognitive theory and task technology fit. Inf Manag. 2008:45:410-7.

75. D'Ambra J, Wilson CS, Akter S. Application of the task-technology fit model to structure and evaluate the adoption of e-books by academics. J Am Soc Inf Sci Technol. 2013;64:48-64.

76. Aljukhadar M, Senecal S, Nantel J. Is more always better? Investigating the task-technology fit theory in an online user context. Inf Manag. 2014;51:391-7.

77. Khan IU, Hameed Z, Yu Y, Islam T, Sheikh Z, Khan SU. Predicting the acceptance of MOOCs in a developing country: application of task-technology fit model, social motivation, and self-determination theory. Telemat Informat. 2018;35:964-78.

78. Klopping IM, Mckinney E. Extending the technology acceptance model and the task-technology fit model to consumer e-commerce. Inf Technol Learn Perform J. 2004;22:35-48.

79. Gan Q, Cao Q. Adoption of electronic health record system: multiple theoretical perspectives. In: 2014 47th Hawaii International Conference on System Sciences (HICSS). 2014;2716-24. http://ieeexplore.ieee.org/document/6758942/.

80. Dennis AR, Wixom BH, Vandenberg RJ. Understanding fit and appropriation effects in group support systems via meta-analysis understanding fit and appropriation effects in group support systems via meta-analysis. Source MIS Q MIS Q. 2001;25:167-93. http://www.jstor.org/stable/3250928\%5Cn, http://about.jstor.org/terms.

81. Pagani M. Determinants of adoption of high speed data services in the business market: evidence for a combined technology acceptance model with task technology fit model. Inf Manag. 2006;43:847-60.

82. Davis FD. Perceived usefulness, perceived ease of use, and user acceptance of information technology. MIS Q. 1989;13:319. http://www.jstor.org/stable/249008?origin=crossref.

83. Dillon A, Morris MG. User acceptance of new information technology: theories and models. Annu Rev Inf Sci Technol. 1996;31:3-32. http://arizona.openrepository.com/arizona/handle/10150/105584.

84. Shahzad F, Xiu GY, Khan I, Wang J. m-Government security response system: predicting citizens' adoption behavior. Int J Hum Comput Interact. 2018. https://doi.org/10.1080/10447318.2018.1516844.

85. Kapoor K, Dwivedi Y, Piercy CN, Lal B, Weerakkody V. RFID integrated systems in libraries: extending TAM model for empirically examining the use. J Enterp Inf Manag. 2014;27:731-58. https://doi.org/10.1108/JEIM-10-2013-0079.

86. Gentry L, Calantone R. A comparison of three models to explain shop-bot use on the web. Psychol Mark. 2002;19:945-56.

87. Chau PYK, Hu PJ-H. Information technology acceptance by individual professionals: a model comparison approach. Decis Sci. 2001;32:699-719. https://doi.org/10.1111/j.1540-5915.2001.tb00978.x.

88. Park SY, Nam M-W, Cha S-B. University students' behavioral intention to use mobile learning: evaluating the technology acceptance model. Br J Educ Technol. 2012;43:592-605. https://doi.org/10.1111/j.1467-8535.2011.01229.x.

89. Pei Y, Xue W, Su Y, Li D. Discussion on influence factors and evaluation of customer experience for B2C E-commerce enterprises. In: 2015 International Conference on Logistics, Informatics and Service Sciences (LISS), 2015. 2015.

90. Prieto JCS, Migueláñez SO, García-Peñalvo FJ. ICTs integration in education: mobile learning and the technology acceptance model (TAM). In: Proceedings of the second international conference on technological ecosystems for enhancing multiculturality. 2014;683-7. https://doi.org/10.1145/2669711.2669974.

91. Rahman N. Factors affecting big data technology adoption Nayem Rahman department of engineering and technology. In: Student Res Symp Pap 10. 2016;0-29. http://pdxscholar.library.pdx.edu/studentsymposium/2016/ Presentations/10.

92. Venkatesh V, Davis FD. A theoretical extension of the technology acceptance model: four longitudinal field studies. Manag Sci. 2000;46:186-204. https://doi.org/10.1287/mnsc.46.2.186.11926.

93. Ibrahim R, Leng NS, Yusoff RCM, Samy GN, Masrom S, Rizman ZI. E-learning acceptance based on technology acceptance model (TAM). J Fundam Appl Sci. 2017;9:871. https://www.ajol.info/index.php/ffas/article/view/165451.

94. Ambak K, Harun NE, Rosli N, Daniel BD, Prasetijo J, Abdullah ME, et al. Driver intention to use electric cars using technology acceptance model. ARPN J Eng Appl Sci. 2016;11:1-4.

95. Claes V, Devriendt E, Tournoy J, Milisen K. Attitudes and perceptions of adults of 60 years and older towards in-home monitoring of the activities of daily living with contactless sensors: an explorative study. Int J Nurs Stud. 2015;52:134-48.

96. Castañeda JA, Muñoz-Leiva F, Luque T. Web acceptance model (WAM): moderating effects of user experience. Inf Manag. 2007:44:384-96.

97. Brock C, Blut M, Linzmajer M, Zimmer B. F-commerce and the crucial role of trust. In: Thirty Second International Conference on Information Systems. 2011; p. 1-11.

98. Venkatesh V, Morris MG, Davis GB, Davis FD. User acceptance of information technology: toward a unified view. MIS Q. 2003;27:425-78.

99. French WL. CHB. Organization development: behavioral science interventions for organization improvement. 6th ed. Upper Saddle River: Prentice Hall; 1999. http://ezproxy.yorks.ac.uk/login?url=, http://search.ebscohost.com/ login.aspx?direct=true\&db=edb\&AN=6266511\&site=eds-live\&scope=site.

100. Zander A. Resistance to change -its analysis and prevention. Adv Manag J. 1950;15:9-11. http://psycnet.apa.org/ psycinfo/1950-06096-001.

101. Oliver C. Strategic responses to institutional processes. Acad Manag Rev. 1991;16:145-79. https://doi.org/10.5465/ AMR.1991.4279002. 
102. Oreg S. Resistance to change: developing an individual differences measure. J Appl Psychol. 2003;88:680-93.

103. Venkatesh V, Morris M, Ackerman P. A longitudinal field investigation of gender differences in individual technology adoption decision-making processes. Organ Behav Hum Decis Process. 2000;83:33-60.

104. Huang RT. Exploring the moderating role of self-management of learning in mobile english learning. Educ Technol Soc. 2014;17:255-67.

105. Kim H-W, Kankanhalli A. Investigating user resistance to information systems implementation: a status quo bias perspective. MIS Q. 2009;33:567-82. http://www.jstor.org/stable/20650309.

106. Nov O, Ye C. Users' personality and perceived ease of use of digital libraries: the case for resistance to change. J Am Soc Inf Sci Technol. 2008:59:845-51.

107. Alomari MK, Sandhu K, Woods P. Exploring citizen perceptions of barriers to e-government adoption in a developing country. Transform Gov People Process Policy. 2014;8:131-50. https://doi.org/10.1108/TG-05-2013-0013.

108. Nov O, Ye C. Resistance to change and the adoption of digital libraries: an integrative model. J Am Soc Inf Sci Technol. 2009;60:1702-8.

109. Beal III L, Stavros JM, Cole ML. Effect of psychological capital and resistance to change on organisational citizenship behaviour. SA J Ind Psychol. 2013;39. http://sajip.co.za/index.php/sajip/article/view/1136.

110. Ford EW, Menachemi N, Peterson LT, Huerta TR. Resistance is futile: but it is slowing the pace of EHR adoption nonetheless. J Am Med Informat Assoc. 2009;16:274-81.

111. Bhattacherjee A, Hikmet N. Physicians' resistance toward healthcare information technology: a theoretical model and empirical test. Eur J Inf Syst. 2007;16:725-37.

112. Di Fabio A, Bernaud J-L, Loarer E. Emotional intelligence or personality in resistance to change? Empirical results in an Italian health care context. J Employ Couns. 2014;51:146-57. https://doi.org/10.1002/j.2161-1920.2014.00048.x.

113. Alkraiji A, Jackson T, Murray I. Barriers to the widespread adoption of health data standards: an exploratory qualitative study in tertiary healthcare organizations in Saudi Arabia. J Med Syst. 2013;37:9895.

114. Jang SH, Kim RH, Lee CW. Effect of u-healthcare service quality on usage intention in a healthcare service. Technol Forecast Soc Change. 2016;113:396-403.

115. Newsted PR, Huff SL, Munro MC. Survey instruments in information systems. MIS Q. 1998;22:553.

116. Cheung CMK, Lee MKO. Understanding the sustainability of a virtual community: model development and empirical test. J Inf Sci. 2009;35:279-98. https://doi.org/10.2307/30036540.

117. Saunders M, Lewis P, Thornhill A. Research methods for business students. Res methods Bus students. 2016;649. http://lib.myilibrary.com/Open.aspx?id=819487\#.

118. Liu H, Chu H, Huang Q, Chen X. Enhancing the flow experience of consumers in China through interpersonal interaction in social commerce. Comput Human Behav. 2016;58:306-14.

119. Byrne BM. Structural equation modeling with AMOS: basics concepts, applications, and programming. Struct Equ Model. 2016. http://www.uta.fi/aktkk/lectures/sem_en/pdf/sem_exercise_v2.4.pdf.

120. Von Der Heidt T, Scott D. Rethinking the role of external collaboration in product innovation. Int J Entrep Innov Manag. 2012;15:59-90. http://www.scopus.com/inward/record.url?eid=2-s2.0-84857306847\&partn erlD $=40 \& m d 5=66 b 5 e 12 d d 28 c 6 c c f 46 e a 9 b c a 98 b f b e 54$

121. Bartlett MS. A note on the multiplying factors for various X2 approximations. J R Stat Soc. 1954;16:296-8. http:// www.jstor.org/stable/2984057.

122. Podsakoff PM, MacKenzie SB, Lee JY, Podsakoff NP. Common method biases in behavioral research: a critical review of the literature and recommended remedies. J Appl Psychol. 2003;88:879-903.

123. Flynn B. Empirical research methods in operations management. J Oper Manag. 1990;9:250-84.

124. Hair JF, Anderson RE, Tatham RL, Black WC. Multivariate data analysis with readings. 5th ed. Prentice-Hill: Up. Saddle River; 1998.

125. Fornell C, Larcker D. Evaluating structural equation models with unobservable variables and measurement error. J Mark Res. 1981;18:39-50. https://doi.org/10.2307/3151312.

126. Hair JF, BlackWC, Babin BJ, Anderson RE. Multivariate data analysis. Vectors. Upper Saddle River: Prentice Hall; 2010. p. 816.

127. Afshan S, Sharif A. Acceptance of mobile banking framework in Pakistan. Telemat Inform. 2016;33:370-87.

\section{Submit your manuscript to a SpringerOpen ${ }^{\circ}$ journal and benefit from:}

- Convenient online submission

- Rigorous peer review

- Open access: articles freely available online

- High visibility within the field

- Retaining the copyright to your article

Submit your next manuscript at $\boldsymbol{\nabla}$ springeropen.com 